\title{
Scientific Rationale for Combination Immunotherapy of Hepatocellular Carcinoma with Anti-PD-1/PD-L1 and Anti-CTLA-4 Antibodies
}

Masatoshi Kudo

Department of Gastroenterology and Hepatology, Kindai University Faculty of Medicine, Osaka-Sayama, Japan

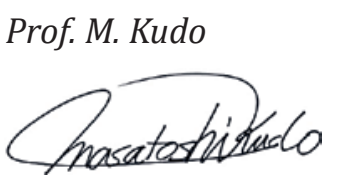

Editor Liver Cancer

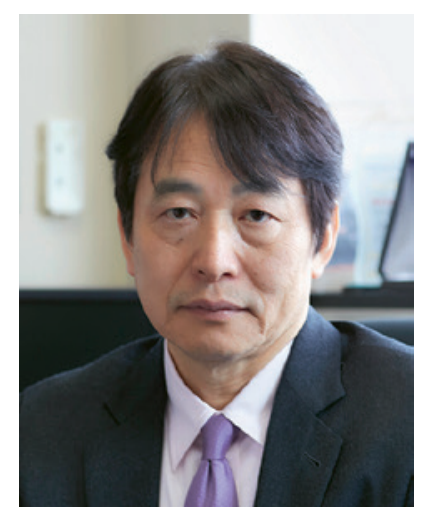

\section{Introduction}

The outcomes of immune checkpoint inhibitor therapies against advanced cancer have greatly exceeded initial expectations since the early clinical studies reported in 2010 [1] and 2012 [2]. It is now evident that immune checkpoint inhibitors are highly effective against multiple solid tumors in addition to malignant melanoma, which was the first malignancy to be studied. Although researchers were initially skeptical about the practical use of conventional cancer immunotherapies that solely enhance immune responses, scientists in both industry and academia are vigorously pursuing the development of anticancer immunotherapies using immune checkpoint inhibitors. In fact, the journal Science designated cancer immunotherapy as the "Breakthrough of the Year" in 2013, and the journal Nature named immune checkpoint blockade in cancer a paradigm shift in cancer treatment. Since then, various industry-academia collaborations have been initiated, and the remarkable strides in this field have been hailed as "the dawn of the new cancer therapy era" [3] and the "renaissance of cancer immunotherapy" [4].

The first immune checkpoint molecule to be described, programmed cell death protein 1 (PD-1), was identified in 1992 by Dr. Tasuku Honjo and colleagues at Kyoto University [5]. 


\section{Liver
Cancer}

\begin{tabular}{|c|c|}
\hline \multicolumn{2}{|l|}{ Liver Cancer 2019;8:413-426 } \\
\hline DOI: 10.1159/000503254 & $\begin{array}{l}\text { (c) } 2019 \text { S. Karger AG, Basel } \\
\text { www.karger.com/lic }\end{array}$ \\
\hline
\end{tabular}

Kudo: Scientific Rationale for Combination Immunotherapy of HCC with Anti-PD-1/ PD-L1 and Anti-CTLA-4 Antibodies

Later it was shown to be involved in immune suppression, and a study with gene-deficient mice revealed that PD-1 serves as a "brake" on the immune response [6]. In 2000, a collaborative research study between Dr. Honjo's group, the Genetic Institute, and a group at Harvard University identified the ligands of PD-1, programmed death ligand 1 (PD-L1) and programmed death ligand 2 (PD-L2) [7, 8]. In 2002, Iwai et al. [6] found that blocking interaction between PD-1 and its ligands enhanced immune activation, resulting in markedly stronger antitumor responses. Based on these findings, a fully human anti-PD-1 antibody was developed in 2005 by Ono Pharmaceutical Co. and Medarex (later acquired by Bristol-Myers Squibb). Nivolumab was approved as an investigational new drug by the FDA in 2006, and clinical trials were initiated in the United States [9]. In 2009, Bristol-Myers Squibb and Ono Pharmaceutical Co. conducted a joint clinical study; in 2014, after several additional clinical trials, nivolumab was approved in Japan for the treatment of malignant melanoma [10]. This was the first time that a PD-1 inhibitor received regulatory approval anywhere in the world. In Japan, nivolumab is currently approved for treatment of non-small-cell lung cancer, renal cell carcinoma, non-Hodgkin's lymphoma, head and neck cancer, gastric cancer, malignant pleural mesothelioma, and malignant melanoma. Merck's anti-PD-1 antibody pembrolizumab is also approved for treating malignant melanoma, non-small-cell lung cancer, Hodgkin's lymphoma, urothelial carcinoma, and unresectable microsatellite instability-high or mismatch repair-deficient metastatic solid cancers.

A series of clinical trials assessing these two anti-PD-1 antibodies for use in the treatment of other types of cancers, including breast cancer, hepatocellular carcinoma (HCC), and bladder cancer, are currently underway, and interim results were reported at meetings of the American Society of Clinical Oncology (ASCO) and the European Society for Medical Oncology. Based on these ongoing investigations, anti-PD-1 and anti-PD-L1 antibodies are now being approved for treatment of many types of cancer.

Meanwhile, in 1995 Krummel and Allison [11] (University of Texas, USA) reported that a different molecule, cytotoxic T lymphocyte-associated protein 4 (CTLA-4), also negatively regulates immune cells, and that administration of an inhibitory antibody against CTLA-4 resulted in tumor regression in mouse models [12]. CTLA-4 is also an immune checkpoint molecule, and in March 2011 the USA approved the anti-CTLA-4 antibody ipilimumab (developed by Bristol-Myers Squibb) for treatment of malignant melanoma; subsequently, it was approved in Europe in July 2011 [13] and in Japan in 2015. Drs. Tasuku Honjo and James Allison won the 2018 Nobel Prize in Physiology or Medicine for their discovery of the inhibitory immune checkpoints PD- 1 and CTLA- 4 and for their immense contributions to cancer therapy.

Several clinical studies assessing anti-PD-1, anti-PD-L1, and/or anti-CTLA-4 antibodies as monotherapies or combination therapies for treatment of HCC are currently underway, and this field is rapidly advancing. This paper outlines the rationale for clinical studies assessing combination immunotherapy using anti-PD-1/PD-L1 and anti-CTLA-4 antibodies.

\section{The Cancer Immunity Cycle and Immune Escape}

Immune responses to tumors can be classified into two phases: the priming phase, which occurs in the lymph node, and the effector phase, which occurs in the tumor tissue. Released cancer antigens are bound by major histocompatibility complex (MHC) molecules expressed on antigen-presenting cells (APCs). These cells migrate to lymph nodes where the antigens are presented to $\mathrm{T}$ cell receptors (TCRs) expressed by immature T cells. Immature T cells are not activated solely by antigen stimulation (the first signal), but require an additional costimulatory signal (the second signal) in order to become fully activated; this second signal is 


\section{Liver Cancer}

\begin{tabular}{l|l}
\hline \multicolumn{2}{l}{ Liver Cancer 2019;8:413-426 } \\
\hline DOI: 10.1159/000503254 & $\begin{array}{l}\text { @ 2019 S. Karger AG, Basel } \\
\text { www.karger.com/lic }\end{array}$ \\
\hline
\end{tabular}

Kudo: Scientific Rationale for Combination Immunotherapy of HCC with Anti-PD-1/ PD-L1 and Anti-CTLA-4 Antibodies

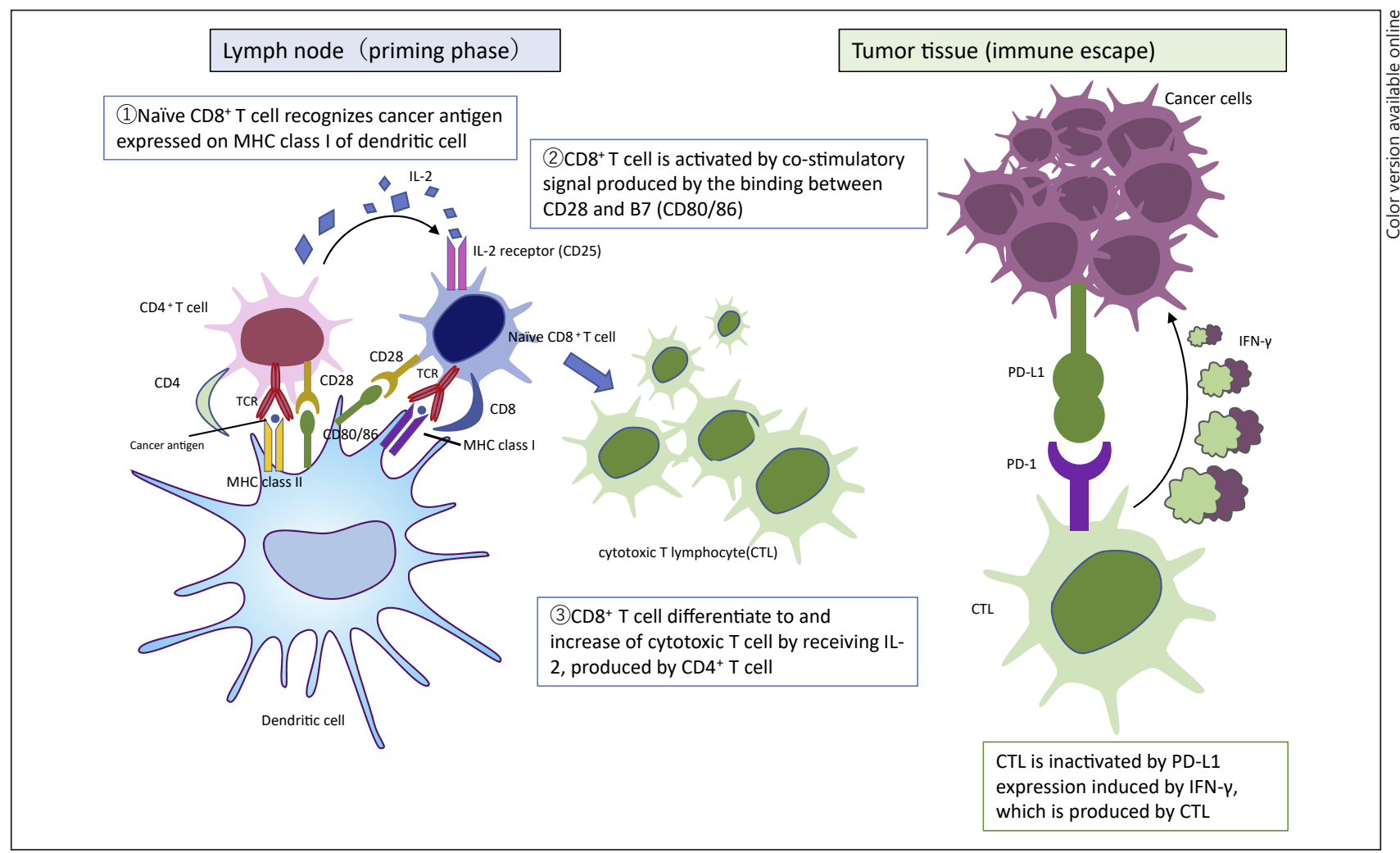

Fig. 1. Activation of cytotoxic T cells. Prepared by the author based on the findings of Yarchoan et al. [15].

delivered by engagement of B7 family molecules (CD80/B7-1 and CD86/B7-2) on APCs with CD28 on T cells (the priming phase). In the priming phase, IL-2 released by CD4-positive cells that are activated by stimulation via MHC class II molecules induces differentiation of CD8-positive T cells into cytotoxic T lymphocytes (CTLs) and promotes their proliferation (Fig. 1). Activated T cells travel via the bloodstream to the tumor, where they infiltrate the tumor tissue. Within the tumor, activated T cells attack tumor cells by releasing perforin and granzyme upon recognition of cancer antigens presented by MHC molecules on tumor cells by TCRs expressed by activated $\mathrm{T}$ cells (the effector phase). The cancer antigens are also recognized by APCs, which migrate to lymph nodes to further activate CD8-positive T cells. This is the cancer immunity cycle (Fig. 2) [14]. Additionally, among the three classes of cancer antigens, neoantigens that are unique to cancer cells are the most antigenic (Table 1) [15].

$\mathrm{T}$ cell attack seems to be effective initially, but weakens over time. When activated CD8-positive cells release humoral factors such as perforin and granzyme, they also release interferon- $\gamma$ (IFN- $\gamma$ ), which binds to IFN- $\gamma$ receptors on cancer cells. This triggers expression of PD-L1 on the cancer cell surface via the signal transducer and activator of transcription 3 (STAT3) pathway, which is one mechanism that contributes to cancer cell escape from immune response (immune escape in cancer, Fig. 1).

There are two main mechanisms of cancer immune escape: one occurs in the lymph nodes and the other at the cancer site. 


\section{Liver Cancer}

\begin{tabular}{l|l}
\hline Liver Cancer 2019;8:413-426 \\
\hline DOI: 10.1159/000503254 & $\begin{array}{l}\text { (c) 2019 S. Karger AG, Basel } \\
\text { www.karger.com/lic }\end{array}$ \\
\hline
\end{tabular}

Kudo: Scientific Rationale for Combination Immunotherapy of HCC with Anti-PD-1/

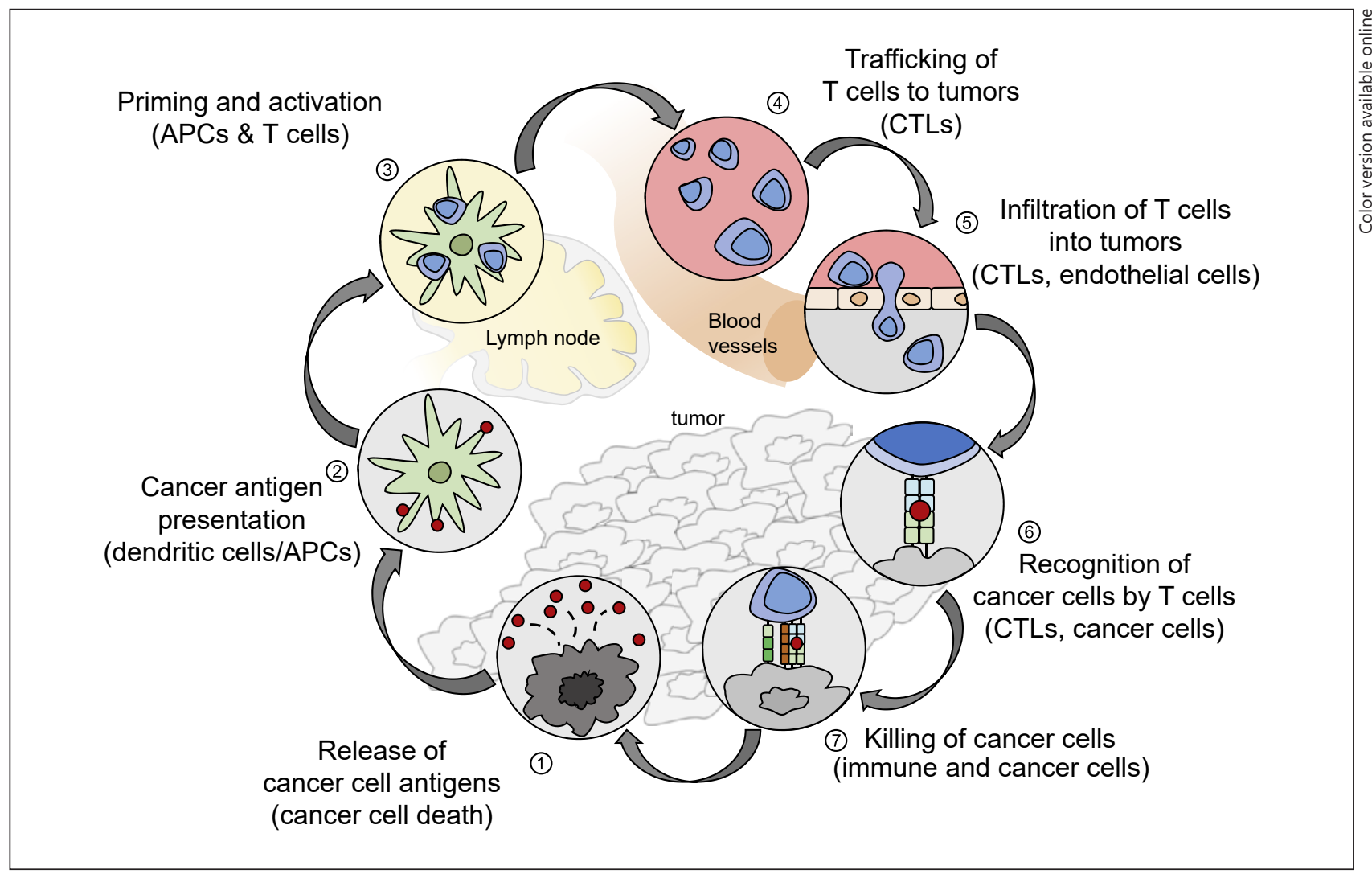

Fig. 2. The cancer immunity cycle. Adapted from Chen and Mellman [14].

Table 1. Classification of cancer antigens (outline of the immune system)

\begin{tabular}{|c|c|c|}
\hline Antigen type & Description & Examples of antigen type \\
\hline $\begin{array}{l}\text { Tumor-specific } \\
\text { antigens } \\
\text { (neoantigens) }\end{array}$ & $\begin{array}{l}\text { Completely absent from normal host cells } \\
\text { Arise in cancer cells from oncogenic viral } \\
\text { proteins or nonsynonymous somatic mutations }\end{array}$ & $\begin{array}{l}\text { HPV oncoproteins E6 and E7 } \\
\text { (HPV-associated cancers of the } \\
\text { cervix, anus, and oropharynx) } \\
\text { Individual KRAS mutations } \\
\text { (pancreatic, colon, lung, and } \\
\text { various other cancers) }\end{array}$ \\
\hline $\begin{array}{l}\text { Tumor-associated } \\
\text { antigens }\end{array}$ & $\begin{array}{l}\text { Low levels of expression on normal host cells } \\
\text { Disproportionately expressed on tumor cells } \\
\text { Often result from genetic amplification or } \\
\text { posttranslational modifications } \\
\text { Can be selectively expressed by the cell lineage } \\
\text { from which the cancer evolved }\end{array}$ & $\begin{array}{l}\text { Her2 (breast cancer etc.) } \\
\text { Mesothelin (pancreatic cancer and } \\
\text { mesothelioma) } \\
\text { CD19 on B cell malignancies }\end{array}$ \\
\hline $\begin{array}{l}\text { Cancer/testis } \\
\text { antigens }\end{array}$ & $\begin{array}{l}\text { Absent on normal adult cells, except in } \\
\text { reproductive tissues (e.g., testes, fetal ovaries, } \\
\text { and trophoblasts) } \\
\text { Selectively expressed by various tumor types }\end{array}$ & $\begin{array}{l}\text { MAGE (various cancers) } \\
\text { NY-ESO-1 antigen (various } \\
\text { cancers) }\end{array}$ \\
\hline
\end{tabular}

Adapted from Yarchoan et al. [15]. 


\section{Liver Cancer}

\begin{tabular}{l|l}
\hline Liver Cancer 2019;8:413-426 \\
\hline DOI: 10.1159/000503254 & $\begin{array}{l}\text { @ 2019 S. Karger AG, Basel } \\
\text { www.karger.com/lic }\end{array}$ \\
\hline
\end{tabular}

Kudo: Scientific Rationale for Combination Immunotherapy of HCC with Anti-PD-1/ PD-L1 and Anti-CTLA-4 Antibodies

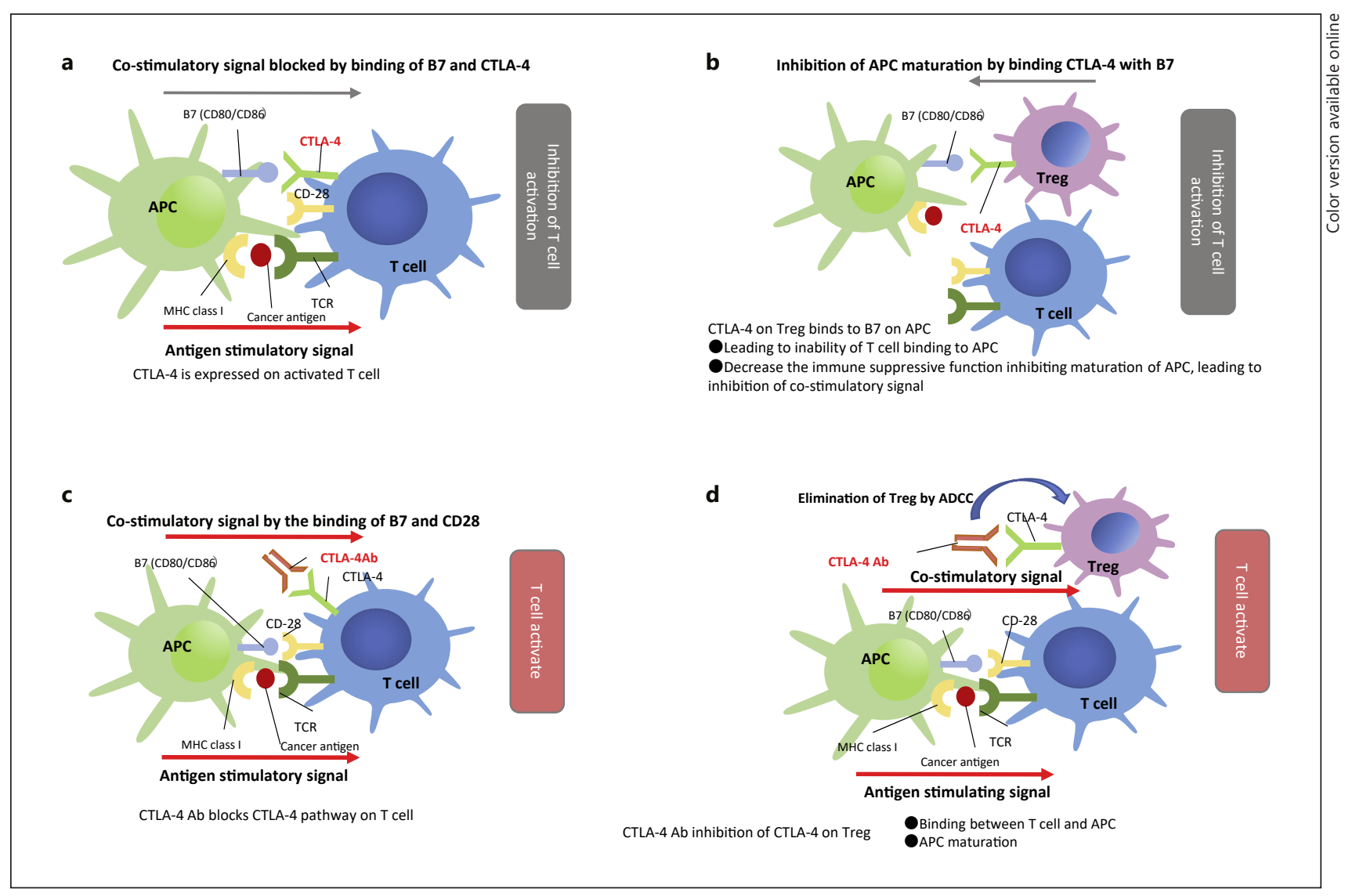

Fig. 3. Inhibitory mechanism of CD8+ T cell activation at the lymph node (priming phase).

\section{Mechanisms of Immune Escape in Cancer}

Immune Escape in the Lymph Nodes (Priming Phase)

Two mechanisms are involved in suppressing T cell activation during the priming phase, resulting in decreased activation and proliferation of cancer-specific naïve T cells. One such mechanism is blockade of the B7/CD28-mediated costimulatory signal by upregulation of CTLA-4 on naïve CD8-positive cells (Fig. 3a). CTLA-4 has 10-fold higher affinity to B7 family costimulatory receptors (CD80/B7-1 and CD86/B7-2) than CD28; thus, it outcompetes CD28 for binding to these receptors, thereby inhibiting transmission of the second costimulatory signal. Under normal conditions, CTLA-4 terminates physiologically unnecessary $\mathrm{T}$ cell activity, thereby regulating excessive $\mathrm{T}$ cell immune responses. However, in cancer immunology, CTLA-4 inhibits activation and proliferation of activated T cells that recognize cancer antigens (Fig. 3a).

Another key player is regulatory T cells (Tregs; Fig. 3b, 4). CTLA-4 is constitutively expressed on Tregs, which suppress the activity of both dendritic cells (DCs) and CD8-positive $\mathrm{T}$ cells. Tregs downregulate expression of costimulatory molecules on DCs directly in a CTLA4-dependent manner. When naïve CD8-positive T cells are activated by these DCs, there is no transmission of the B7-1/B7-2-CD28 costimulatory signal, resulting in induction of anergy rather than activation (Fig. 3b, 4). Tregs also express the high-affinity form of the IL-2 receptor (CD25) and thus compete with naïve CD8-positive T cells for IL-2, which is essential for acti- 


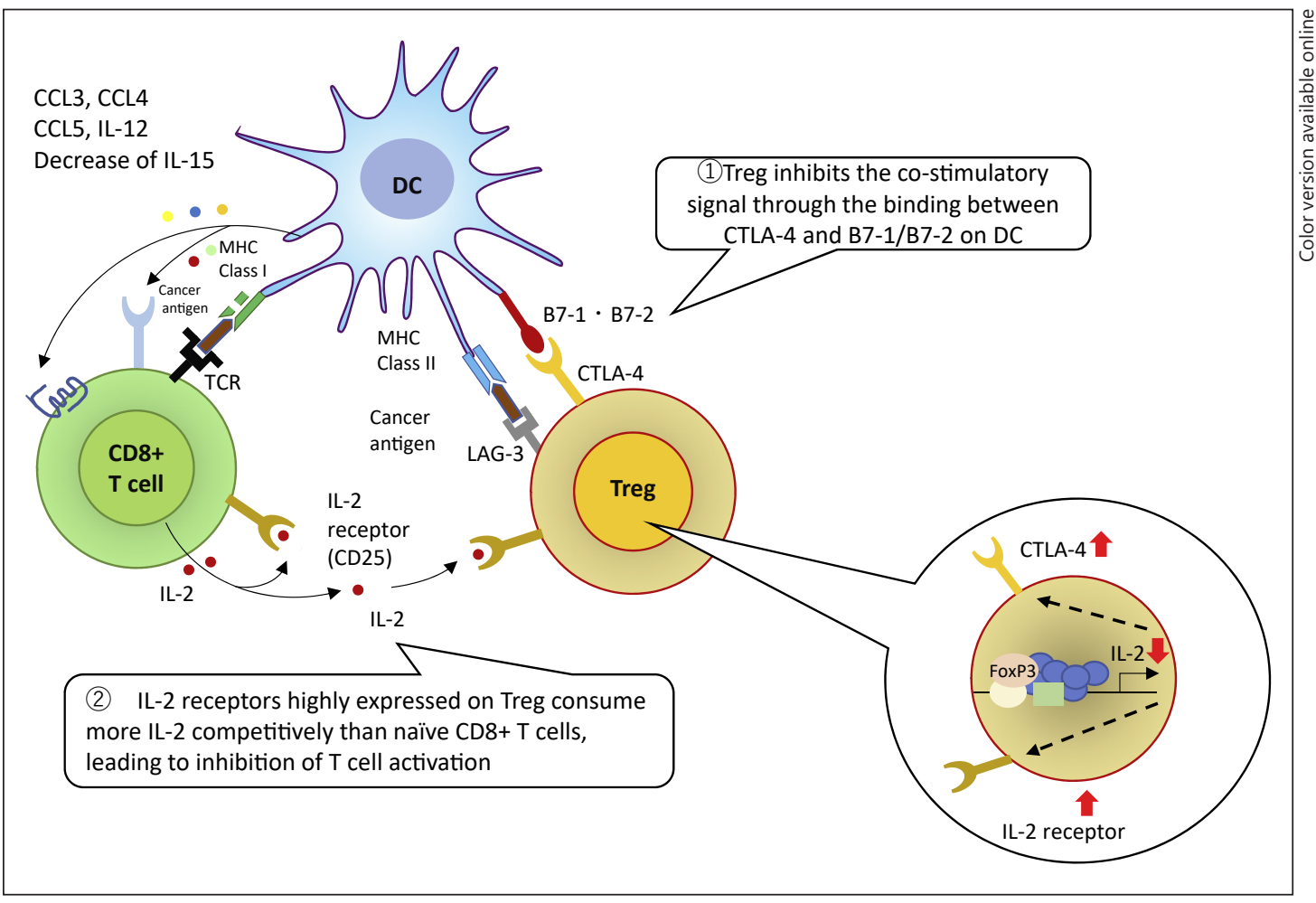

Fig. 4. Regulatory $\mathrm{T}$ cell function at the priming phase. Modified from Laidlaw et al. [16] and Tanaka and Sakaguchi [17].

vation of naïve T cells (Fig. 4) [16-21]. At the same time, Tregs decrease production of IL-12 and IL-15 by DCs, thereby inhibiting CD25 expression on naïve CD8-positive T cells and consequently preventing their activation (Fig. 4) [16-21].

Anti-CTLA-4 therapies aim to release the "brake" from T cell activation in the lymph node. As mentioned earlier, the first example of anti-CTLA-4 therapy was demonstrated by Krummel and Allison [11], who showed that tumors in mice could be eradicated by administering antibodies that block CTLA-4. Anti-CTLA-4 antibodies have two roles (Table 2): they block CTLA-4 to restore costimulatory signaling triggered by B7/CD28 binding on T cells (Fig. 3c), and they eliminate Tregs via antibody-dependent cellular cytotoxicity, thereby enhancing $\mathrm{T}$ cell activation (Fig. 3d).

At present, clinical studies are investigating the efficacy of the anti-CTLA-4 antibodies ipilimumab and tremelimumab against numerous solid tumors.

\section{Immune Escape at the Tumor Site (Effector Phase)}

PD-1, an immunosuppressive accessory signal receptor expressed on activated T cells, B cells, and cells of the myeloid lineage, binds to PD-L1 and PD-L2 to suppress T cell activation in an antigen-specific manner. PD-L1 is expressed widely in blood vessels, cardiac muscle, lung, and placenta as well as on DCs, whereas PD-L2 is expressed only on DCs.

PD-1 is not highly expressed in the peripheral blood of normal mice or healthy humans. After an immune response has been triggered by infection or inflammation, it becomes expressed selectively on T cells in the late stage of activation. Expression is particularly strong on effector $\mathrm{T}$ cells in peripheral tissues. 


\section{Liver Cancer}

\begin{tabular}{l|l}
\hline Liver Cancer 2019:8:413-426 \\
\hline DOI: 10.1159/000503254 & $\begin{array}{l}\text { @ 2019 S. Karger AG, Basel } \\
\text { www.karger.com/lic }\end{array}$ \\
\hline
\end{tabular}

Kudo: Scientific Rationale for Combination Immunotherapy of HCC with Anti-PD-1/ PD-L1 and Anti-CTLA-4 Antibodies

Table 2. Inactivation mechanism of CD8+ cells at the lymph node (priming phase) and activation by antiCTLA-4 and PD-1/PD-L1 antibody

Activation mechanism of CD8+ T cells
Inactivation mechanism of CD8+ T cells
Activation of CTLs by combination of PD-1/PD-L1 and CTLA-4

(1) TCR of naïve CD8+ T cells recognizes cancer antigen presented on MHC class I on APCs
(1) CTLA-4 expressed on Tregs inhibits maturation of DCs and decreases antigen presentation
(1) Anti CTLA-4 antibody decreases Treg function and number, leading to activation
(2) Costimulatory signal transduction by binding CD80 on CD8+ T cells and B7-1/B7-2 (CD80/86) on APCs

(3) Differentiation to and upregulation of CTLs by receiving IL-2 by IL-2 receptor expressed on $\mathrm{CD} 8+\mathrm{T}$ cells, which is produced by CD $4+\mathrm{T}$ cells
(2) Tregs inhibit CTLs by

consuming IL-2 and by cAMP

transport
(3) CTLA-4 on activated CTLs upregulates the binding between CTLA-4 and B7-1/B7-2, resulting in downregulation of the CTLs
(2) Anti-CTLA-4 antibody upregulates CTL activation

(4) PD-L1 expressed on APCs binds to PD-1, leading to inacti(3) Anti-PD-1/PD-L1 activates CTLS

vation of CTLS

APCs, antigen-presenting cells; CTL, cytotoxic T lymphocyte; CTLA-4, cytotoxic T lymphocyte-associated protein 4; DCs, dendritic cells; MHC, major histocompatibility complex; PD-1, programmed cell death protein 1; PD-L1, programmed death ligand 1; TCR, T cell receptor; Treg, regulatory T cell.

In contrast to PD-1, PD-L1 is expressed constitutively in normal peripheral tissues and by almost all immune cells (including T and B cells) after activation. PD-L1 is expressed by most cancer cells through the mechanism described below.

Meanwhile, expression of PD-L2 is limited to professional APCs; thus, it is thought to be involved only in T cell activation in the lymph node. For this reason, it is generally thought that PD-1 antibodies and PD-L1 antibodies work via a similar mechanism, whereas the utility of anti-PD-L2 antibodies in cancer immunotherapy is limited.

When TCRs on activated T cells recognize cancer antigens presented on MHC molecules, $\mathrm{T}$ cells release perforin and granzyme to attack tumor cells directly; they also release cytokines (e.g., IFN- $\gamma$ ), which act on cancer cells. In cancer cells, activation of IFN- $\gamma$ receptors results in induction of STAT3 signaling, eventually leading to increased cell surface expression of PD-L1. Upon binding of PD-L1 to PD-1 on CTLs, a negative signal is transmitted, which weakens T cell-mediated attacks on cancer cells (immune escape; Fig. 5).

This brake can be released by administration of anti-PD-1/PD-L1 antibodies, which restores immune attack against tumor cells (Fig. 5). In other words, this approach restores preexisting anticancer immunity [22-33]; thus, it is completely different from conventional chemotherapies and molecular targeted therapies. Anti-PD-L1 antibodies are thought to have a similar effect [2]. PD-L1 is a biomarker for the efficacy of anti-PD-1 therapy [34]; however, it must be noted that anti-PD-1 therapy is effective against some tumors that lack PD-L1 expression.

The role of Tregs in suppressing T cell activation during the priming phase was described earlier. Tregs are also involved in immune escape at the tumor tissue during the effector 


\section{Liver Cancer}

\begin{tabular}{l|l}
\hline Liver Cancer 2019;8:413-426 \\
\hline DOI: 10.1159/000503254 & $\begin{array}{l}\text { (c) 2019 S. Karger AG, Basel } \\
\text { www.karger.com/lic }\end{array}$ \\
\hline
\end{tabular}

Kudo: Scientific Rationale for Combination Immunotherapy of HCC with Anti-PD-1/ PD-L1 and Anti-CTLA-4 Antibodies

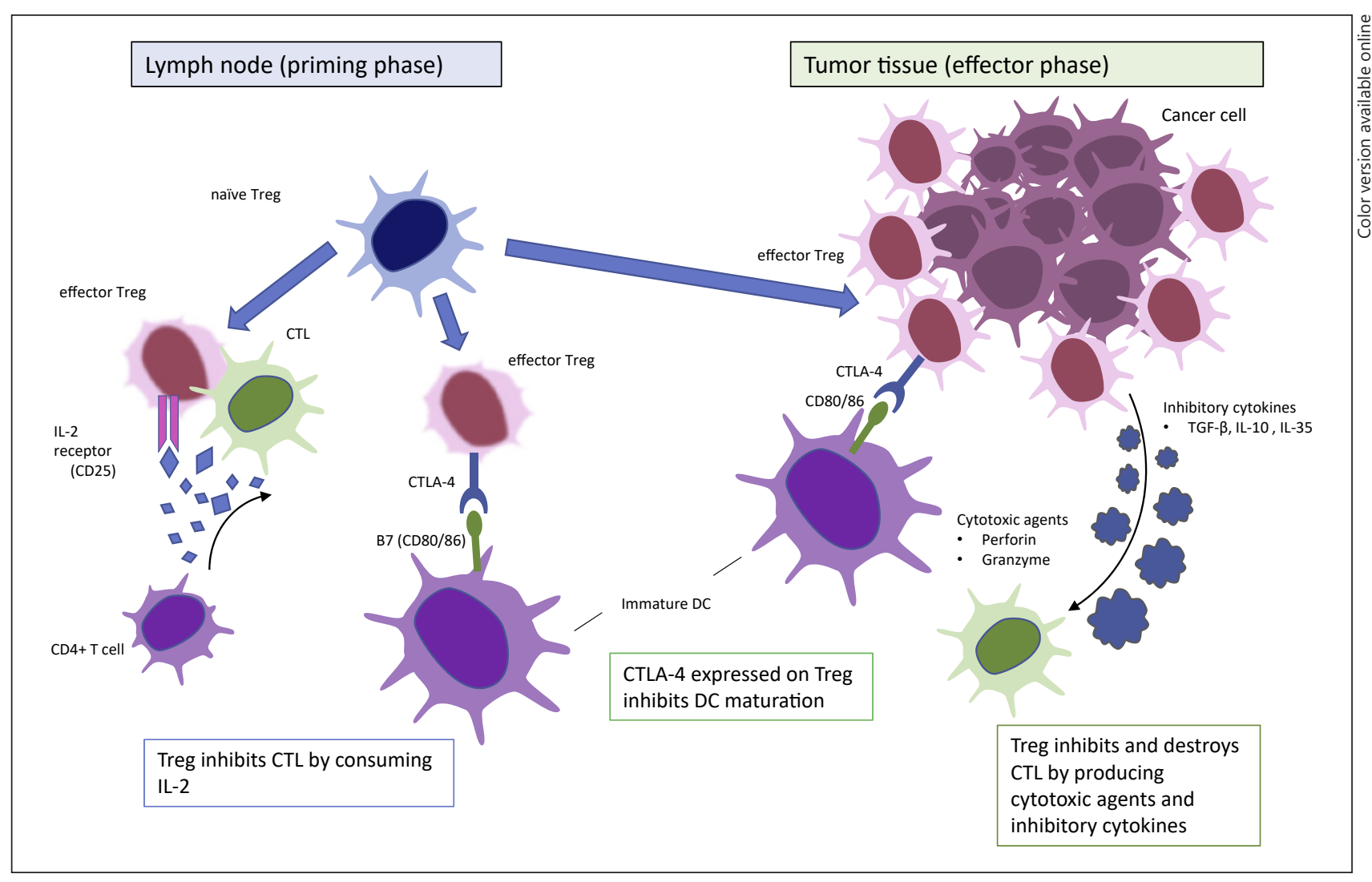

Fig. 5. Regulatory T cells are associated with cancer immune escape both at the priming and effector phases.

phase (Fig. 6). Peripheral Tregs are naïve T cells, while most Tregs at cancer sites are effector $\mathrm{T}$ cells that produce immunosuppressive cytokines (e.g., transforming growth factor- $\beta$ [TGF- $\beta$ ], IL-10, or IL-35) and cytotoxic molecules (e.g., granzyme and perforin), which attack or inhibit activated T cells (Fig. 6) [18-21]. Anti-CTLA-4 antibodies are effective at suppressing these actions of Tregs (Table 3).

\section{The Importance of Tregs and the Rationale Underlying Combined Use of Anti-PD-1/PD-L1 and Anti-CTLA-4 Antibodies}

Because of the constitutive and high-level surface expression of CTLA- 4 by Tregs, antiCTLA-4 antibodies restore activation of CTLs in the lymph nodes and activate CTLs at cancer sites by modulating the immunosuppressive microenvironment. For this reason, combined use of anti-PD-1/PD-L1 and anti-CTLA-4 antibodies is both rational and reasonable.

\section{Combination Therapies Using Anti-PD-1/PD-L1 and Anti-CTLA-4 Antibodies}

The efficacy of such combination therapies for treatment of malignant melanoma has already been demonstrated [35], and these combinations are currently being tested for use in the treatment of HCC [36-38]. The rationale for combination therapies using anti-PD-1/ 


\section{Liver Cancer}

\begin{tabular}{l|l}
\hline \multicolumn{2}{l}{ Liver Cancer 2019;8:413-426 } \\
\hline DOI: 10.1159/000503254 & $\begin{array}{l}\text { (c) 2019 S. Karger AG, Basel } \\
\text { www.karger.com/lic }\end{array}$ \\
\hline
\end{tabular}

Kudo: Scientific Rationale for Combination Immunotherapy of HCC with Anti-PD-1/ PD-L1 and Anti-CTLA-4 Antibodies

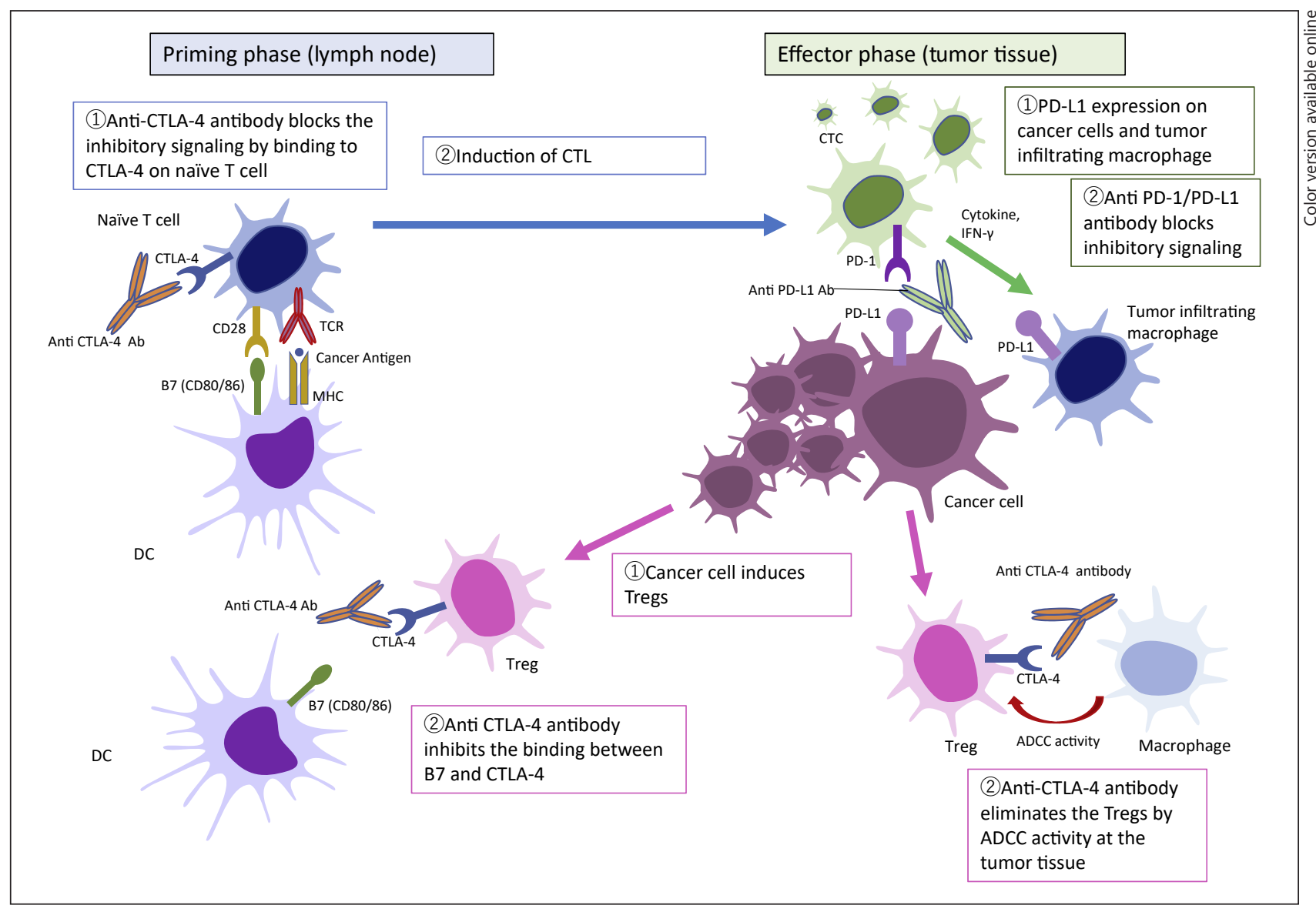

Fig. 6. Restoration of tumor immunity by blocking the CTLA-4 and PD-1/PD-L1 pathways. ADCC, antibodydependent cellular cytotoxicity.

Table 3. Immune escape and immune activation at the cancer tissue level

\begin{tabular}{|c|c|c|}
\hline Immune response & Immune escape & $\begin{array}{l}\text { Immune activation by a } \\
\text { combination of PD-1, PD-L1, } \\
\text { and CTLA- } 4 \text { antibodies }\end{array}$ \\
\hline
\end{tabular}

(1) TCRs on CTLs recognize the cancer antigen presented on MHC class I of cancer cells, leading to attack on cancer cells by releasing perforin and granzyme
(1) IFN- $\gamma$ produced by attack on cancer cell by activated CTLs, leading to PD-L1 expression through STAT3 signaling, which results in inhibition of activated CTLS
(1) PD-1/PD-L1 antibody binds to PD-L1 expressed on tumor cells or macrophages, leading to activation of CTLs
(2) Tregs in the tumor microenvironment inhibit and destroy CTLs by releasing perforin, granzyme, or inhibitory cytokines (TGF- $\beta$, IL-10, IL-35, etc.)
(2) CTLA-4 antibodies eliminate Tregs by ADCC activity 
Kudo: Scientific Rationale for Combination Immunotherapy of HCC with Anti-PD-1/

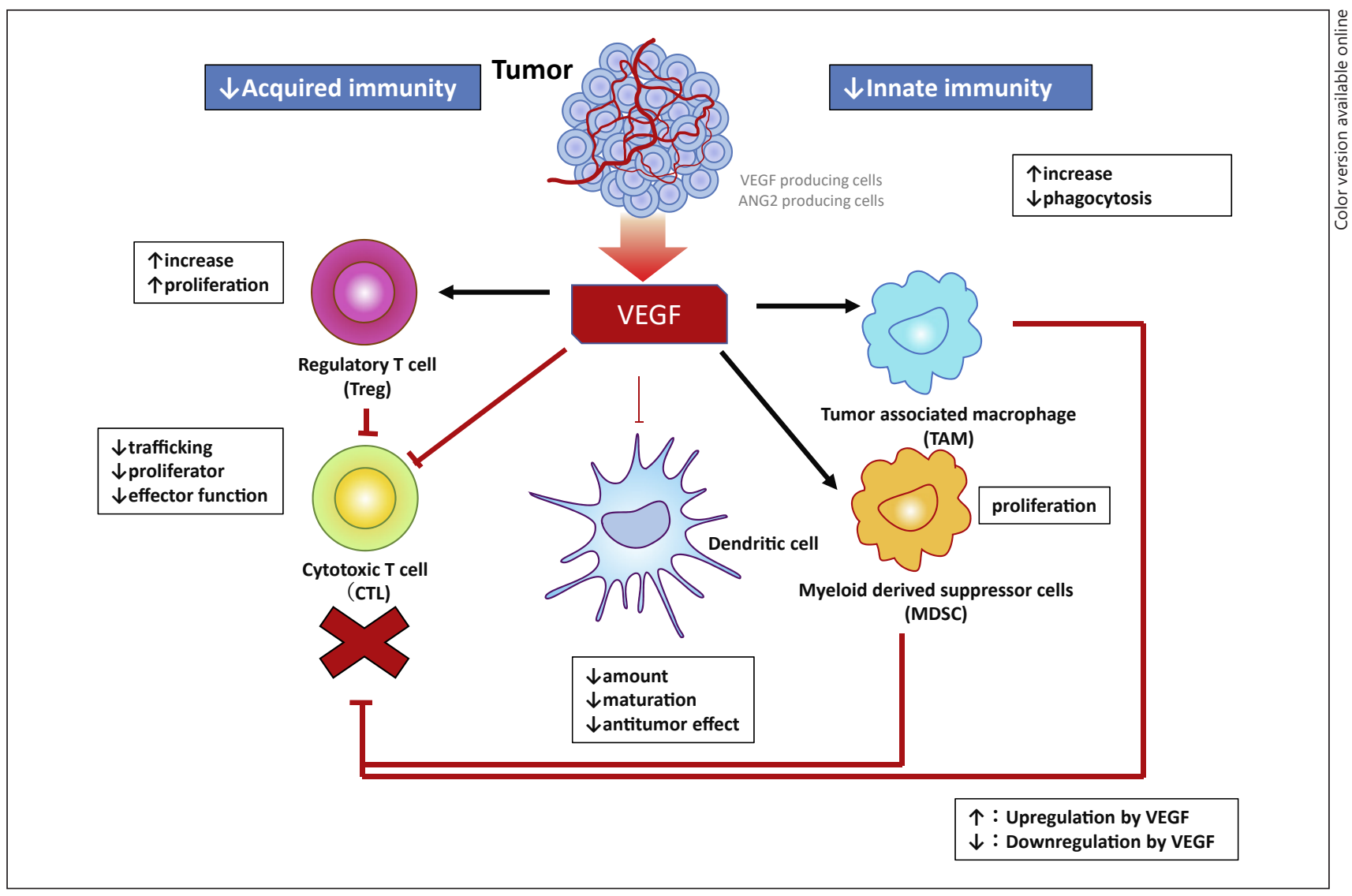

Fig. 7. Direct action of vascular endothelial growth factor on immune cells and tumor microenvironment. Modified from Fukumura et al. [41].

PD-L1 and anti-CTLA-4 antibodies is that blockade of the PD-1/PD-L1 pathway does not induce antitumor immunity if antigen-specific CD8-positive T cells are not present in cancer tissues; however, blockade of the B7-CTLA-4 pathway leads to increased activation of CD8-positive cells in the lymph nodes as well as increased infiltration of activated CD8-positive $\mathrm{T}$ cells into the tumor. Based on this rationale, several studies assessing the combination of anti-CTLA-4 and anti-PD-1/PD-L1 antibodies for treatment of HCC are currently underway [38].

The results of the CheckMate 040 study, which tested different dose levels and dosing intervals of nivolumab and the anti-CTLA-4 antibody ipilimumab, were reported at ASCO 2019 [37]. In addition, a phase I/II study investigating combination of the anti-PD-1 antibody (durvalumab) with an anti-CTLA-4 antibody (tremelimumab) showed a favorable objective response rate of $25.0 \%$ in 40 patients with HCC [39]. The phase III study (HIMALAYA) is currently underway.

\section{Problems with Modulating the Immunosuppressive Microenvironment}

As described earlier, the combination of nivolumab and ipilimumab was more effective against melanoma than monotherapy [40]. However, under hypoxic conditions, which are a characteristic feature of solid cancers such as liver cancer, vascular endothelial growth factor 
Kudo: Scientific Rationale for Combination Immunotherapy of HCC with Anti-PD-1/ PD-L1 and Anti-CTLA-4 Antibodies

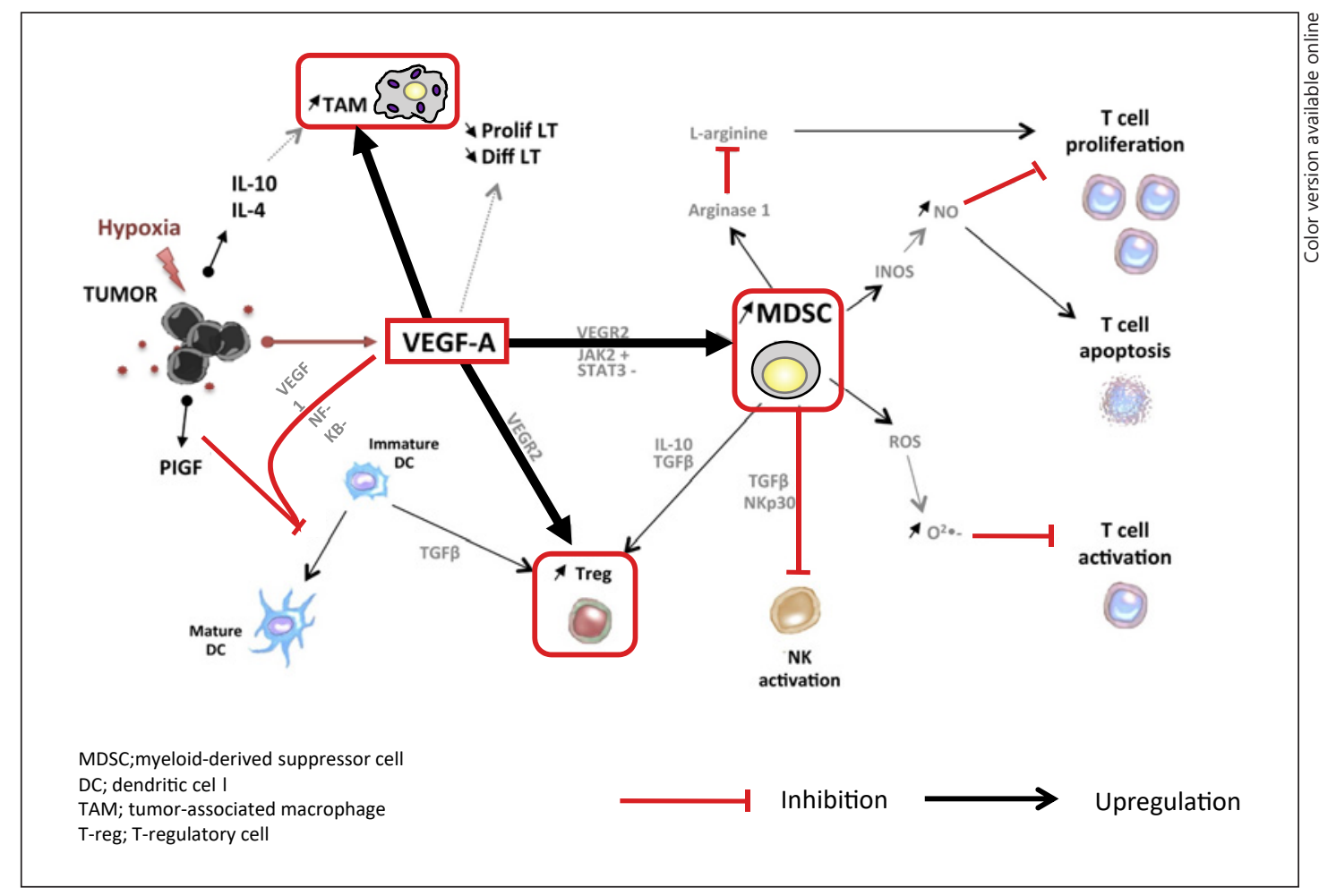

Fig. 8. Immunosuppressive tumor microenvironment produced by vascular endothelial growth factor. Adapted from Voron et al. [43].

(VEGF) influences immunosuppressive Tregs as well as tumor-associated macrophages and myeloid-derived suppressor cells, which release immunosuppressive cytokines such as IL-10 and TGF- $\beta$ (Fig. 7,8 ) [41-43]. It may be difficult to modulate such complex immunosuppressive microenvironments solely using anti-PD-1/PD-L1 antibodies and anti-CTLA-4 antibodies.

Various studies testing combinations of an immune checkpoint inhibitor and an agent targeting VEGF are currently underway. A nonclinical study showed that combination therapy with pembrolizumab and lenvatinib modulated an immunosuppressive tumor microenvironment rich in tumor-associated macrophages and Tregs. Combination therapy reduced secretion of TGF- $\beta$ and IL-10, increased secretion of IL-12, and inhibited expression of PD-1 and Tim3, thereby inducing an antitumor immune response [44]. In fact, both response rate and disease control rate were highest with the pembrolizumab-lenvatinib combination among several combination trials (Table 4) [37, 39, 45-50].

Therefore, combination of a PD-1/PD-L1 antibody, an anti-CTLA-4 antibody, and a welltolerated anti-VEGF antibody such as bevacizumab or ramucirumab is both rational and ideal, and clinical studies of such triple regimens are anticipated.

\section{Conclusions}

Sharma and Allison $[13,51]$ suggested that long-term survival can be expected in patients who achieve a clinical response to immune checkpoint inhibitors, and that the particularly high efficacy of combination therapies may offer an opportunity to achieve real 
Kudo: Scientific Rationale for Combination Immunotherapy of HCC with Anti-PD-1/ PD-L1 and Anti-CTLA-4 Antibodies

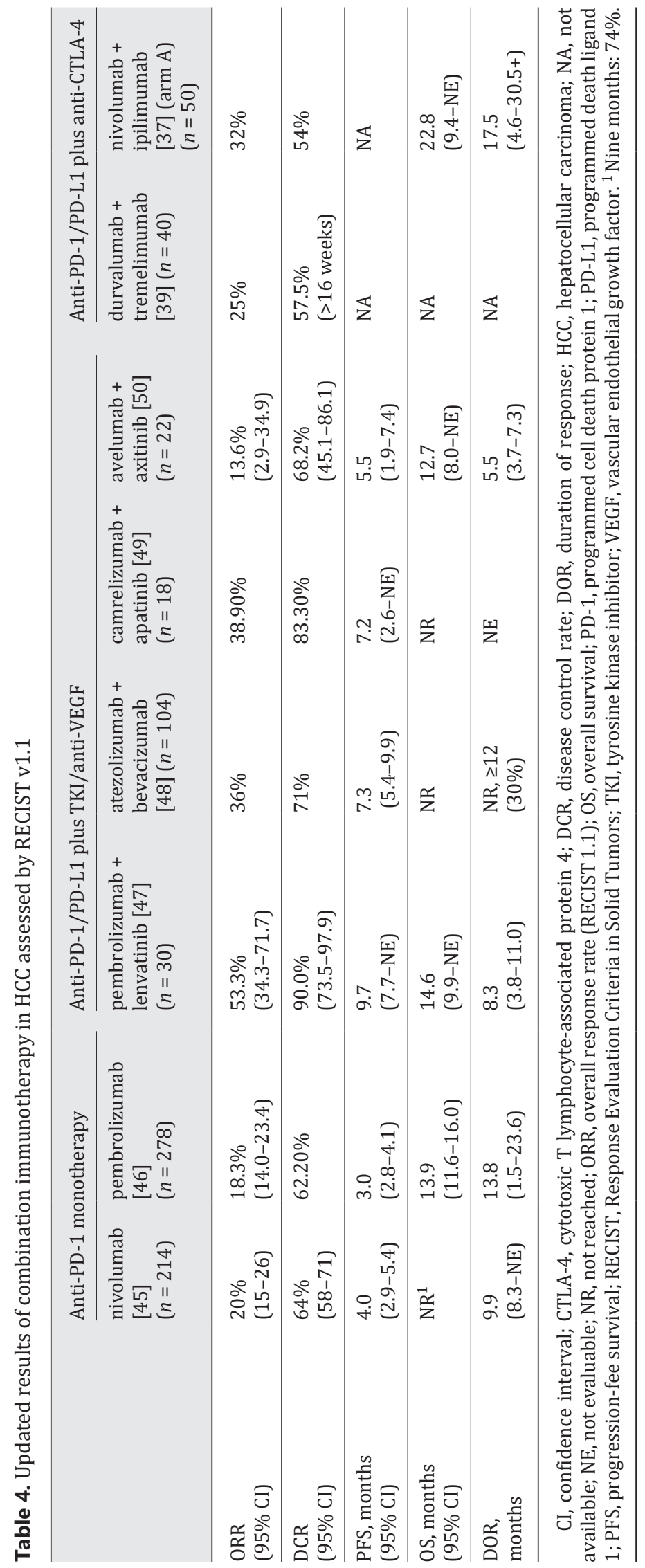


Kudo: Scientific Rationale for Combination Immunotherapy of HCC with Anti-PD-1/ PD-L1 and Anti-CTLA-4 Antibodies

cures. Immune checkpoint inhibitors are expected to improve survival of those with HCC. Their combination with other therapies that modulate the immune status of the tumor microenvironment, such as anti-VEGF therapies, may lead to a paradigm shift in liver cancer treatment.

\section{Disclosure Statement}

Masatoshi Kudo received lecture fees from Bayer, Eisai, MSD, and Ajinomoto, research grants from Chugai, Otsuka, Takeda, Taiho, Sumitomo Dainippon, Daiichi Sankyo, MSD, Eisai, Bayer, AbbVie, Medico's Hirata, Astellas Pharma, and Bristol-Myers Squibb, and advisory consulting fees from Kowa, MSD, BristolMyers Squibb, Bayer, Chugai, Taiho, Eisai, and Ono Pharmaceutical.

\section{References}

1 Hodi FS, O’Day SJ, McDermott DF, Weber RW, Sosman JA, Haanen JB, et al. Improved survival with ipilimumab in patients with metastatic melanoma. N Engl J Med. 2010 Aug;363(8):711-23.

2 Brahmer JR, Tykodi SS, Chow LQ, Hwu WJ, Topalian SL, Hwu P, et al. Safety and activity of anti-PD-L1 antibody in patients with advanced cancer. N Engl J Med. 2012 Jun;366(26):2455-65.

3 Mellman I, Coukos G, Dranoff G. Cancer immunotherapy comes of age. Nature. 2011 Dec;480(7378):480-9.

4 Kirkwood JM, Butterfield LH, Tarhini AA, Zarour H, Kalinski P, Ferrone S. Immunotherapy of cancer in 2012. CA Cancer J Clin. 2012 Sep-0ct;62(5):309-35.

5 Ishida Y, Agata Y, Shibahara K, Honjo T. Induced expression of PD-1, a novel member of the immunoglobulin gene superfamily, upon programmed cell death. EMBO J. 1992 Nov;11(11):3887-95.

6 Iwai Y, Ishida M, Tanaka Y, Okazaki T, Honjo T, Minato N. Involvement of PD-L1 on tumor cells in the escape from host immune system and tumor immunotherapy by PD-L1 blockade. Proc Natl Acad Sci USA. 2002 Sep; 99(19):12293-7.

7 Freeman GJ, Long AJ, Iwai Y, Bourque K, Chernova T, Nishimura H, et al. Engagement of the PD-1 immunoinhibitory receptor by a novel $\mathrm{B} 7$ family member leads to negative regulation of lymphocyte activation. J Exp Med. 2000 Oct;192(7):1027-34.

8 Latchman Y, Wood CR, Chernova T, Chaudhary D, Borde M, Chernova I, et al. PD-L2 is a second ligand for PD-1 and inhibits T cell activation. Nat Immunol. 2001 Mar;2(3):261-8.

9 Okazaki T, Honjo T. PD-1 and PD-1 ligands: from discovery to clinical application. Int Immunol. 2007 Jul;19(7): 813-24.

10 Robert C, Long GV, Brady B, Dutriaux C, Maio M, Mortier L, et al. Nivolumab in previously untreated melanoma without BRAF mutation. N Engl J Med. 2015 Jan;372(4):320-30.

11 Krummel MF, Allison JP. CD28 and CTLA-4 have opposing effects on the response of T cells to stimulation. J Exp Med. 1995 Aug;182(2):459-65.

12 Leach DR, Krummel MF, Allison JP. Enhancement of antitumor immunity by CTLA-4 blockade. Science. 1996 Mar;271(5256):1734-6.

13 Sharma P, Allison JP. The future of immune checkpoint therapy. Science. 2015 Apr;348(6230):56-61.

14 Chen DS, Mellman I. Oncology meets immunology: the cancer-immunity cycle. Immunity. 2013 Jul;39(1):1-10.

15 Yarchoan M, Johnson BA 3rd, Lutz ER, Laheru DA, Jaffee EM. Targeting neoantigens to augment antitumour immunity. Nat Rev Cancer. 2017 Apr;17(4):209-22.

16 Laidlaw BJ, Craft JE, Kaech SM. The multifaceted role of CD4(+) T cells in CD8(+) T cell memory. Nat Rev Immunol. 2016 Feb;16(2):102-11.

17 Tanaka A, Sakaguchi S. Regulatory T cells in cancer immunotherapy. Cell Res. 2017 Jan;27(1):109-18.

18 Sakaguchi S, Miyara M, Costantino CM, Hafler DA. FOXP3+ regulatory T cells in the human immune system. Nat Rev Immunol. 2010 Jul;10(7):490-500.

19 Setoguchi R, Hori S, Takahashi T, Sakaguchi S. Homeostatic maintenance of natural Foxp3(+) CD25(+) CD4(+) regulatory T cells by interleukin (IL)-2 and induction of autoimmune disease by IL-2 neutralization. J Exp Med. 2005 Mar;201(5):723-35.

20 Vignali DA, Collison LW, Workman CJ. How regulatory T cells work. Nat Rev Immunol. 2008 Jul;8(7):523-32.

21 Cao X, Cai SF, Fehniger TA, Song J, Collins LI, Piwnica-Worms DR, et al. Granzyme B and perforin are important for regulatory T cell-mediated suppression of tumor clearance. Immunity. 2007 0ct;27(4):635-46.

22 Sznol M, Chen L. Antagonist antibodies to PD-1 and B7-H1 (PD-L1) in the treatment of advanced human cancer. Clin Cancer Res. 2013 Mar;19(5):1021-34.

23 Herbst RS, Soria JC, Kowanetz M, Fine GD, Hamid O, Gordon MS, et al. Predictive correlates of response to the anti-PD-L1 antibody MPDL3280A in cancer patients. Nature. 2014 Nov;515(7528):563-7.

24 Shih K, Arkenau HT, Infante JR. Clinical impact of checkpoint inhibitors as novel cancer therapies. Drugs. 2014 Nov; 74(17):1993-2013. 
25 Philips GK, Atkins M. Therapeutic uses of anti-PD-1 and anti-PD-L1 antibodies. Int Immunol. 2015 Jan;27(1): 39-46.

26 Mahoney KM, Freeman GJ, McDermott DF. The Next Immune-Checkpoint Inhibitors: PD-1/PD-L1 Blockade in Melanoma. Clin Ther. 2015 Apr;37(4):764-82.

27 Harshman LC, Drake CG, Wargo JA, Sharma P, Bhardwaj N. Cancer immunotherapy highlights from the 2014 ASCO Meeting. Cancer Immunol Res. 2014 Aug;2(8):714-9.

28 Topalian SL, Drake CG, Pardoll DM. Targeting the PD-1/B7-H1(PD-L1) pathway to activate anti-tumor immunity. Curr Opin Immunol. 2012 Apr;24(2):207-12.

29 Merelli B, Massi D, Cattaneo L, Mandalà M. Targeting the PD1/PD-L1 axis in melanoma: biological rationale, clinical challenges and opportunities. Crit Rev Oncol Hematol. 2014 Jan;89(1):140-65.

30 Le DT, Uram JN, Wang H, Bartlett BR, Kemberling H, Eyring AD, et al. PD-1 Blockade in Tumors with MismatchRepair Deficiency. N Engl J Med. 2015 Jun;372(26):2509-20.

31 Droeser RA, Hirt C, Viehl CT, Frey DM, Nebiker C, Huber X, et al. Clinical impact of programmed cell death ligand 1 expression in colorectal cancer. Eur J Cancer. 2013 Jun;49(9):2233-42.

32 Ribas A. Tumor immunotherapy directed at PD-1. N Engl J Med. 2012 Jun;366(26):2517-9.

33 Hamid O, Robert C, Daud A, Hodi FS, Hwu WJ, Kefford R, et al. Safety and tumor responses with lambrolizumab (anti-PD-1) in melanoma. N Engl J Med. 2013 Jul;369(2):134-44.

34 Gao Q, Wang XY, Qiu SJ, Yamato I, Sho M, Nakajima Y, et al. Overexpression of PD-L1 significantly associates with tumor aggressiveness and postoperative recurrence in human hepatocellular carcinoma. Clin Cancer Res. 2009 Feb;15(3):971-9.

35 Larkin J, Chiarion-Sileni V, Gonzalez R, Grob JJ, Cowey CL, Lao CD, et al. Combined Nivolumab and Ipilimumab or Monotherapy in Untreated Melanoma. N Engl J Med. 2015 Jul;373(1):23-34.

36 Kudo M. Molecular Targeted Agents for Hepatocellular Carcinoma: Current Status and Future Perspectives. Liver Cancer. 2017 Feb;6(2):101-12.

37 Yau T, Kang YK, Kim TY, El-Khoueiry AB, Santoro A, Sangro B, et al. Nivolumab (NIVO) + ipilimumab (IPI) combination therapy in patients (pts) with advanced hepatocellular carcinoma (aHCC): results from CheckMate 040. J Clin Oncol. 2019;37(suppl):abstr 4012.

38 Kudo M. Immuno-oncology therapy for hepatocellular carcinoma: current status and ongoing trials. Liver Cancer. 2019;8(4):221-38.

39 Kelley RK, Abou-Alfa GK, Bendell JC, Kim TY, Borad MJ, Yong WP, et al. Phase I/II study of durvalumab and tremelimumab in patients with unresectable hepatocellular carcinoma(HCC): phase I safety and efficacy analyses. J Clin Oncol. 2017;35(suppl):abstr 4073.

40 Postow MA, Chesney J, Pavlick AC, Robert C, Grossmann K, McDermott D, et al. Nivolumab and ipilimumab versus ipilimumab in untreated melanoma. N Engl J Med. 2015 May;372(21):2006-17.

41 Fukumura D, Kloepper J, Amoozgar Z, Duda DG, Jain RK. Enhancing cancer immunotherapy using antiangiogenics: opportunities and challenges. Nat Rev Clin Oncol. 2018 May;15(5):325-40.

42 Chouaib S, Messai Y, Couve S, Escudier B, Hasmim M, Noman MZ. Hypoxia promotes tumor growth in linking angiogenesis to immune escape. Front Immunol. 2012 Feb;3:21.

43 Voron T, Marcheteau E, Pernot S, Colussi O, Tartour E, Taieb J, et al. Control of the immune response by proangiogenic factors. Front Oncol. 2014 Apr;4:70.

44 Kato Y, Tabata K, Kimura T, Yachie-Kinoshita A, Ozawa Y, Yamada K, et al. Lenvatinib plus anti-PD-1 antibody combination treatment activates CD8+ T cells through reduction of tumor-associated macrophage and activation of the interferon pathway. PLoS One. 2019 Feb;14(2):e0212513.

45 El-Khoueiry AB, Sangro B, Yau T, Crocenzi TS, Kudo M, Hsu C, et al. Nivolumab in patients with advanced hepatocellular carcinoma (CheckMate 040): an open-label, non-comparative, phase 1/2 dose escalation and expansion trial. Lancet. 2017 Jun;389(10088):2492-502.

46 Zhu AX, Finn RS, Edeline J, Cattan S, Ogasawara S, Palmer D, et al.; KEYNOTE-224 investigators. Pembrolizumab in patients with advanced hepatocellular carcinoma previously treated with sorafenib (KEYNOTE224): a non-randomised, open-label phase 2 trial. Lancet Oncol. 2018 Jul;19(7):940-52.

47 Ikeda M, Sung MW, Kudo M, Kobayashi M, Baron AD, Finn RS: A phase 1b trial of lenvatinib (LEN) plus pembrolizumab (PEM) in patients (pts) with unresectable hepatocellular carcinoma (uHCC). J Clin Oncol. 2018; 36(suppl):abstr 4076.

48 Lee MS, Pishvaian MJ, Ryoo BY, et al. Atezolizumab + bevacizumab in previously untreated patients with unresectable or advanced hepatocellular carcinoma: analysis of a phase Ib study. APPLE, 0-034, August 31, 2019.

49 Xu JM, Zhang Y, Jia R, Wang Y, Liu R, Zhang G, et al. Anti-programmed death-1 antibody SHR-1210 (S) combined with apatinib (A) for advanced hepatocellular carcinoma (HCC), gastric cancer (GC) or esophagogastric junction (EGJ) cancer refractory to standard therapy: a phase 1 trial. J Clin Oncol. 2018;36(suppl):abstr 4075.

50 Kudo M, Motomura K, Wada Y, Inaba Y, Sakamoto Y, Kurosaki M, et al. First-line avelumab + axitinib in patients with advanced hepatocellular carcinoma: results from a phase 1b trial (VEGF Liver 100). J Clin Oncol. 2019; 37 (suppl):abstr 4072.

51 Sharma P, Allison JP. Immune checkpoint targeting in cancer therapy: toward combination strategies with curative potential. Cell. 2015 Apr;161(2):205-14. 